\title{
Whole Genome Sequence of Wilsonomyces Carpophilus, the Causal Agent of Shot Hole of Stone Fruits: Insights Into Secreted Proteins of a Necrotrophic Fungal Repository
}

\section{Mahiya Farooq}

Plant Virology and Molecular Pathology Laboratory, Division of Plant Pathology, SKUAST-K

Mehraj D. Shah ( $D$ mehraj547@rediffmail.com)

Sher-e-Kashmir University of Agricultural Sciences and Technology of Kashmir

Bilal A. Padder

Plant Virology and Molecular Pathology Laboratory, Division of Plant Pathology, SKUAST-K

\section{T.A. Sofi}

Plant Virology and Molecular Pathology Laboratory, Division of Plant Pathology, SKUAST-K

Khalid k. Masoodi

Plant Virology and Molecular Pathology Laboratory, Division of Plant Pathology, SKUAST-K

Asha Nabi

Plant Virology and Molecular Pathology Laboratory, Division of Plant Pathology, SKUAST-K

\section{Sumaira Hamid}

Plant Virology and Molecular Pathology Laboratory, Division of Plant Pathology, SKUAST-K

Mushtaq Ahmad

Division of Biotechnology, FOH, SKUAST-K

\section{Research Article}

Keywords: Stigmina blight, Thyrostroma carpophilum, Illumina HiSeq, PacBio, Next Generation Sequencing (NGS)

Posted Date: May 27th, 2021

DOl: https://doi.org/10.21203/rs.3.rs-541535/v1

License: (9) (1) This work is licensed under a Creative Commons Attribution 4.0 International License. Read Full License 


\section{Abstract}

Wilsonomyces carpophilus is a necrotrophic plant pathogenic fungus with a wide host range infecting all stone fruits such as peach, plum, apricot and cherry, and almonds among the nut crops. Necrotrophs are more devastating with a complex pathogenicity mechanism and least known effector repositories. Here, we report a 29.9 megabase draft genome assembly of $W$. carpophilus. We explored the hybrid technology of Illumina HiSeq and PacBio sequencing technologies to get the unbiased results of sequence reads. We aligned short Illumina reads against the long PacBio reads. A total of 10,901 protein-coding genes were predicted that includes varied set of genes such as HET genes, cytochrome-p450 genes, kinases etc. We mined 2851 simple sequence repeats (SSRs) in the genome assembly. We also predicted the diverse inventory of secretory proteins, transporters, primary and secondary metabolic enzymes. A total of 225 secreted proteins, hydrolases, polysaccharide-degrading enzymes, esterolytic, lipolytic and proteolytic enzymes were the most significant proteins reflecting the necrotrophic lifestyle of the W. carpophilus. We also identified 146 tRNAs and 52 rRNAs in the pathogen genome.

\section{Introduction}

The stone fruits that includes peach, plum, cherry, apricot, nectarine and, almonds among nut crops are important crops grown throughout the world. The foremost growing countries are America, Australia, Afghanistan, China, Iran, Italy, Greece, France, New Zealand, Portugal, India and Central Asian countries of earlier USSR ${ }^{1}$. Among the number of biotic factors affecting stone fruits among, shot hole disease caused by Wilsonomyces carpophilus is of paramount importance ${ }^{2}$. Shot hole disease is one of the major fungal foliar diseases in Prunus species worldwide ${ }^{3}$. The disease is reported from Africa, Asia, America (North, South, Central), Australia and Oceania ${ }^{4}$. Recently, ${ }^{5}$ reported the shot hole disease of stone fruits (Prunus spp.) as a major threat to the wild-fruit forest of the Western Tianshan Mountains of China. The shot hole disease of Prunus spp. is also reported from California and Poland (https://nt.arsgrin.gov/ fungaldatabas-es/). In literature, a number of synonymous exits for the pathogen such as Thyrostroma carpophilum, Stigmina carpophila and $W$.carpophilus, however, recently ${ }^{6}$ proposed $W$. carpophilus to name the pathogen. The intermittent outbreak of the disease causes notable yield losses ranging from 30 to $90 \%$ in cherry, and about $60.3 \%$ in apricot in Malatya province of Turkey ${ }^{1}$. The disease appear as small circular reddish or purplish lesion with yellow halo, the centre gradually enlarges and become necrotic that ultimately fall down leaving a shot hole appearance ${ }^{7}$. The fungus shows cross pathogenicity on different hosts under in vitro conditions ${ }^{8}$ suggesting that the pathogen lacks specificity towards a particular host species and therefore causes disease in all the stone fruits, and almonds in nut crops. Such studies indicates broad host range of the pathogen and therefore needs profound study before devising a better management capsule. Existence of high pathological and molecular diversity in W. carpophilus hampers resistance breeding, a viable disease management alternative ${ }^{1}$.

In literature, a number of synonym such as Clasterosporium carpophilum (Lev.), Stigmina carpophila (Lev.), Thyrostroma carpophilum and W. carpophilus exists for the pathogen ${ }^{9}$, However, recently, ${ }^{6}$ 
considered W. carpophilus as a causal organism of shot hole disease of Prunus spp. W. carpophilus is an orphan plant pathogen in terms of studies conducted in Prunus - shot hole interface. Although high pathogen diversity and successful development of an ATMT protocol ${ }^{1,10}$, for the fungus increased our understanding but many basic questions related to pathosystem warrants additional research.

Genome sequencing of plant pathogens has provided the insights on pathogen life style besides it changed conventional genetics to genomics. Over last few years, hundreds of plant pathogenic fungal genomes have been decoded and pangenomics currently provide deep insights on pathogenicity and life style characteristics of plant pathogens ${ }^{11,12}$. To gain the evolutionary insights about the poorly studied $W$. carpophilus fungus, it is necessary to exploit the high throughput sequencing toolbox for understanding its life style and evolutionary dynamics. Based on the feeding habit, $W$. carpophilus is a necrotroph and to infect diverse Prunus spp., the pathogen need to be equipped with pathogenicity arsenals that have the capacity to breach pathogen triggered as well as effector triggered immunity of Prunus hosts. Besides secreting the chain of enzymes to degrade the host tissues, nectrotrophs exploit the cell death machinery of the host ${ }^{13}$. Therefore, effectors, the pathogen-encoded secreted proteins play crucial roles in necrotrophs to evade host defense system. Since, it is necessary to understand the pathogenicity mechanism of $W$. carpophilus and studies are needed on how the pathogen is able to manipulate the host cell machinery. Decoding genomes coupled with the fine-tuned bioinformatics pipelines have increased our knowledge about the pathogenicity mechanisms and provided insights on role of secreted effector molecules to evade host defenses. Here we report the first genome draft of $W$. carpophilus with an aim to gain insights on Prunus- shot hole pathogen interaction and fungus pathogenicity mechanism. Decoding the $W$. carpophilus genome using hybrid NGS technology provided us clues about its host defense mechanism evading capabilities and the pathogenicity armory the pathogen is harboring in its genome that makes it a successful pathogen of all Prunus hosts.

\section{Methods}

\section{Fungal culture preparation}

The pathogen was isolated from the shot hole infected leaves of stone fruits viz., plum, peach, apricot, and cherry and almonds among nut crops grown in University orchard of SKUAST-K, Shalimar, Srinagar (J\&K). The purified fungal culture was maintained on Asthana and Hawker's and potato dextrose agar (PDA) ${ }^{10,14}$ media. On the basis of morpho-cultural characteristics, the pathogen was identified as Wilsonomyces carpophilus synonym Thyrostroma carpophilum $\mathrm{Nabi}^{1,10}$. The pathogenicity of these isolates was carried out by detached leaf technique on their respective hosts ${ }^{15}$ followed by their cross infectivity on different stone fruits including almond.

\section{DNA isolationfor whole genome sequencing}

The most virulent isolate of the pathogen based on minimum incubation time and symptom development, was selected for whole genome sequencing. The DNA of the pathogen isolate was 
extracted using XcelGen DNA isolation Kit (Xceleris, Ahmedabad, India) according to the manufacturer instructions. The quality and quantity of extracted DNA was checked using a Qubit 2.0 Fluorimeter (Life Technologies Ltd., Paisley, UK). The integrity of DNA (DIN) was checked using Bioanalyser 2100 (Agilent Technologies, Santa Clara, CA).

\section{Library preparation and genome sequencing}

The DNA Library was prepared using NEBNext Ultra DNA Library Prep Kit (Biolabs, England). The library preparation process was initiated with 200ng DNA. The adapters were ligated to both ends of the DNA fragments. These adapters contain sequences essential for binding dual-barcoded libraries to a flow cell for sequencing and PCR amplification. To ensure maximum yield from a limited amounts of starting material, a high-fidelity amplification step was performed using PCR Master Mix.

The whole genome of plant pathogenic fungus W. carpophilus was decoded using Illumina HiSeq and PacBio sequencing technologies. De Novo assembly of high quality paired end reads was accomplished using Velvet v1.2.10 and the assembly was optimized at Kmer-79 (Supplementary Table 2.) (Fig. 7). Further, scaffolding was performed on pre-assembled contigs taking long reads of PacBio using SSPACELongRead v1.1. We aligned Illumina short reads on PacBio long reads (a hybrid approach) using PBJelly software and GapCloser v1.12 to increase the precision of base calling.

\section{Gene prediction and annotation}

The assembled genome was subjected to gene prediction using Augustus v2.5.5 for the identification of coding sequences. The predicted protein coding genes were subjected to similarity search against NCBI's non-redundant (nr) database using Uniprot, KOG and Pfam database of BLASTP algorithm with an evalue threshold of $1 \mathrm{e}-5$. Simultaneously, all the proteins were searched for similarity against BLASTP with an e-value threshold of $1 \mathrm{e}-5$. Comparative analysis of gene annotation in different database was carried out using http://www.interactivenn.net/. Gene Ontology (GO) annotation was obtained using nr database through Blast2GO command line v-1.4.1. GO sequence distributions helps in specifying all the annotated nodes comprising of GO functional groups. Genes associated with the similar functions were assigned to same $\mathrm{GO}$ functional group. The GO sequence distribution was analyzed for all the three $\mathrm{GO}$ domains i.e. biological processes, molecular function and cellular components.

\section{Secretome mining}

The secretool was used to predict $W$. carpophilus secretome that enables secretome predictions out of amino acid sequence files (http://genomics.cicbiogune.es/SECRETOOL/Secretool.php). The Signal-P (v4.1) and WoLF PSORT (v0.2) were used to identify signal peptides and extracellular localizations in total of 10901 protein coding genes. The TMHMM (v2.0) and PredGPI (http://gpcr.biocomp.unibo.it/predgpi/pred.htm) were used to eliminate sequences with transmembrane domains, ER-retention signal and GPI (glycosylphosphatidyl inositol)-anchors, respectively (Fig. 8).

\section{Simple sequence repeats}


A high-throughput SSR search to identify mono- to hexa- nucleotide SSR motifs was performed using MlcroSAtellite (MISA) identification tool (http://pgrc.ipk-gatersleben.de/misa/download/misa.pl) with default parameters. The default parameters were used so that di-nucleotide pattern should appear at least six times, whereas tri-, tetra-, penta- and hexa- nucleotide motifs should appear five times.

\section{Pathway analysis}

Pathway analysis, ortholog assignment and mapping of genes to the biological pathways were performed using KEGG automatic annotation server (KAAS). All the gene sequences were compared against the KEGG database using BLASTP with threshold bit-score value of 60 (default).

\section{Identification of tRNAs and rRNAs in the genome}

To identify probable tRNA genes, we used tRNAscan-SE that allows detection of unusual tRNA species with accurate prediction of secondary structures. It includes both prokaryotic and eukaryotic selenocysteine tRNA genes, tRNA-derived repetitive elements and pseudogenes. The RNAmmer 1.2 was used for rRNA gene identification.

\section{Collection of diseased planting material / samples}

Necessary permission whenever required was obtained, and all the guidelines and legislation were followed for the collection of diseased planting material or samples from University orchard, SKUAST-K, Shalimar, Srinagar (J\&K), India

\section{Results}

The introduction of novel sequencing technologies such as PacBio has revolutionized the genomic studies. Long read sequencing platforms are used to determine the complex genomic regions that are difficult to explore with short read length sequencing technologies. However, these long-read sequencing technologies are prone to higher error rates also, therefore, in a present study, we explored hybrid approach of Illumina HiSeq and PacBio to decipher the high quality whole genome sequence of Wilsonomyces carpophilus, a plant pathogenic fungus for its announcement for the first time. The genome assembly of $W$. carpophilus shows that the hybrid approach of sequencing is effective in constructing contigs with almost full length genes. To authenticate the genome assembly, we assessed the completeness of the gene space using different softwares and found that the most of the core eukaryotic conserved genes were represented in the assembled genome. It is also commendable that we found 10901 genes using gene prediction algorithm. When these genes were blasted against the $\mathrm{nr}$ database, most of the tophits were against the Pyrenochaeta spp. followed by Ascochyta rabiei. Pyrenochaeta genus is comprised of a wide range of species infecting plants and humans. We found that the plant pathogenic species of Pyrenochaeta behaves similarly as that of $W$. carpophilus and no sexual stage (mating) has been reported in Pyrenochaeta lycopersici (a plant pathogenic fungus) ${ }^{16}$ as well as in W. carpophilus in the nature ${ }^{17-19}$. Interestingly, the pathogen genome also lacks MAT genes that are the 
key factors to decide either sexual or asexual reproduction occurring in the fungus. This evidence clearly shows that the fungus is incompetent for sexual reproduction. Thus, the variability of fungus can be potentially due to the vegetative hyphal fusion or anastomosis, and is evident from the presence of HET genes in the $W$. carpophilus genome. The viable heterokaryon is formed by anastomosis only when individuals have same set of HET genotype, whereas individuals with different HET genotypes forms incompatible vegetative heterokaryon which later on undergoes programmed cell death ${ }^{20}$. The advantage of this is to limit the contamination of the pathogen and other lethal replicons between the strains ${ }^{21}$. The selective pressure is probably responsible for the broad diversification of HET genes and play a key role in the transfer of genetic information between the strains, and variability in the pathogen is indispensable for the adaptation to the environment and to overcome the host defense mechanisms. The other key genes deployed in the pathogen genome were antimicrobial peptide (AMP) binding genes that are used by the pathogen to surmount host defense. These AMPs are the part of plant's innate immunity system against the pathogen attack ${ }^{22}$. The pathogen has an ability to bind these genes in order to surpass plant defense system. AMPs are naturally synthesized low molecular products [up to 100 amino acids (AAs)] that are structurally and biochemically diverse in nature. The diversity in the AMPs suggests the diversity of AMP binding genes in the pathogen that ultimately explaining its diverse host range. We also found cytochrome P450, pKinases, sugar transporters etc. in the pathogen genome. The cytochrome P450 gene is a heme containing protein that are involved in the degradation of plant derived toxins and therefore plays an important role in fungal development eventually in pathogenesis ${ }^{23}$. Higher number of CYPs also indicates the wide host range of the pathogen requiring more toxins to overcome the phytoalexins. Similarly protein kinases play an important role in various key processes of the fungal life cycle such as growth direction, nutrient uptake, stress responses and reproduction ${ }^{24}$, thus can be an important factor in the infection process of the pathogen. Secretory proteins also play a crucial role in the fungal pathogenesis and colonization, and a set of secretory proteins suggests the feeding habit of the pathogen as biotroph, hemibiotroph or necrotroph. The efficiency and hostility of the phytopathogens are often associated with the presence of cell wall degrading enzymes. The first and foremost obstacle to fungal pathogens in plants is the cell wall and its associated components. Plant pathogenic fungi secrete a concoction of hydrolytic enzymes known as carbohydrate-active enzymes (CAZymes), that are required to degrade the cell wall components of the host ${ }^{25}$. The presences of cell wall degrading enzymes such as glycosidases, glucanases, carboxylesterases, laccases, pectatelyases, cellulases etc. in the $W$. carpophilus genome are more often predicted in necrotrophs. The secretion and presence of these enzymes in the $W$. carpophilus showed its stronger resemblance to the necrotrophic plant pathogens. Unlike biotrophs, the necrotrophs have significantly expanded set of cell wall degrading enzymes, thus secretome of the $W$. carpophilus suggests necrotrophic behavior of the pathogen. The secretome of the fungus revealed some other proteins that also suggests its necrotrophic behavior such as FAD binding domains that have ability to catalyse various biochemical reactions and are mainly involved in electron transport chain ${ }^{26}$. We also found some other secretory proteins such as chaperone proteins also known as heat shock proteins that play an important role in the pathogenesis. They maintain the integrity of the pathogen in the adverse conditions, thus making it more viable for infection ${ }^{27}$. Laccasse precursor that 
plays an important role in lignin depolymerization of infected host ${ }^{28}$ and number of other enzymes such as endo-1, 4-beta-galactosidase, cutinase, rhamnogalacturonan lyase, pectin-esterase, pectate lyase, lipolytic protein etc. that play a crucial role in the pathogenicity. Surprisingly, some pathogenicity determinants that plays a role in disarming the host defense such as mycelial catalases that are known to degrade the hydrogen peroxide produced by the host as a result of oxidative burst to kill the pathogen

${ }^{29}$. The presence of these enzymes suggests that the pathogen secrete diverse proteins that co-ordinate in an organized manner to cause disease and evade the host defense. However, these pathogenicity determinants need further characterization and validation to get in depth insight of pathogenicity mechanism of the fungus. In our previous study, we were successful in transforming the fungus by using random ATMT method and the transformants were unable to cause the disease ${ }^{10}$. However, the present study has revealed the number of pathogenicity genes that can be easily targeted to render pathogen ineffective. The present study has opened new opportunities for the comprehensive genomic study of a variety of biological, metabolic and pathological aspects that make the $W$. carpophilus a successful necrotrophic pathogen. Therefore, it is an opportune time to go beyond the conventional neutral genetics by identifying, analyzing, site specific targeting of pathogenicity determinants and re-modelling the core effector repositories.

\section{Discussion}

The introduction of novel sequencing technologies such as PacBio has revolutionized the genomic studies. Long read sequencing platforms are used to determine the complex genomic regions that are difficult to explore with short read length sequencing technologies. However, these long-read sequencing technologies are prone to higher error rates also, therefore, in a present study, we explored hybrid approach of Illumina HiSeq and PacBio to decipher the high quality whole genome sequence of Wilsonomyces carpophilus, a plant pathogenic fungus for its announcement for the first time. The genome assembly of $W$. carpophilus shows that the hybrid approach of sequencing is effective in constructing contigs with almost full length genes. To authenticate the genome assembly, we assessed the completeness of the gene space using different softwares and found that the most of the core eukaryotic conserved genes were represented in the assembled genome. It is also commendable that we found 10901 genes using gene prediction algorithm. When these genes were blasted against the $\mathrm{nr}$ database, most of the tophits were against the Pyrenochaeta spp. followed by Ascochyta rabiei. Pyrenochaeta genus is comprised of a wide range of species infecting plants and humans. We found that the plant pathogenic species of Pyrenochaeta behaves similarly as that of $W$. carpophilus and no sexual stage (mating) has been reported in Pyrenochaeta lycopersici (a plant pathogenic fungus) ${ }^{16}$ as well as in W. carpophilus in the nature ${ }^{17-19}$. Interestingly, the pathogen genome also lacks MAT genes that are the key factors to decide either sexual or asexual reproduction occurring in the fungus. This evidence clearly shows that the fungus is incompetent for sexual reproduction. Thus, the variability of fungus can be potentially due to the vegetative hyphal fusion or anastomosis, and is evident from the presence of HET genes in the $W$. carpophilus genome. The viable heterokaryon is formed by anastomosis only when individuals have same set of HET genotype, whereas individuals with different HET genotypes forms 
incompatible vegetative heterokaryon which later on undergoes programmed cell death ${ }^{20}$. The advantage of this is to limit the contamination of the pathogen and other lethal replicons between the strains ${ }^{21}$. The selective pressure is probably responsible for the broad diversification of HET genes and play a key role in the transfer of genetic information between the strains, and variability in the pathogen is indispensable for the adaptation to the environment and to overcome the host defense mechanisms. The other key genes deployed in the pathogen genome were antimicrobial peptide (AMP) binding genes that are used by the pathogen to surmount host defense. These AMPs are the part of plant's innate immunity system against the pathogen attack ${ }^{22}$. The pathogen has an ability to bind these genes in order to surpass plant defense system. AMPs are naturally synthesized low molecular products [up to 100 amino acids (AAs)] that are structurally and biochemically diverse in nature. The diversity in the AMPs suggests the diversity of AMP binding genes in the pathogen that ultimately explaining its diverse host range. We also found cytochrome P450, pKinases, sugar transporters etc. in the pathogen genome. The cytochrome P450 gene is a heme containing protein that are involved in the degradation of plant derived toxins and therefore plays an important role in fungal development eventually in pathogenesis ${ }^{23}$. Higher number of CYPs also indicates the wide host range of the pathogen requiring more toxins to overcome the phytoalexins. Similarly protein kinases play an important role in various key processes of the fungal life cycle such as growth direction, nutrient uptake, stress responses and reproduction ${ }^{24}$, thus can be an important factor in the infection process of the pathogen. Secretory proteins also play a crucial role in the fungal pathogenesis and colonization, and a set of secretory proteins suggests the feeding habit of the pathogen as biotroph, hemibiotroph or necrotroph. The efficiency and hostility of the phytopathogens are often associated with the presence of cell wall degrading enzymes. The first and foremost obstacle to fungal pathogens in plants is the cell wall and its associated components. Plant pathogenic fungi secrete a concoction of hydrolytic enzymes known as carbohydrate-active enzymes (CAZymes), that are required to degrade the cell wall components of the host ${ }^{25}$. The presences of cell wall degrading enzymes such as glycosidases, glucanases, carboxylesterases, laccases, pectatelyases, cellulases etc. in the $W$. carpophilus genome are more often predicted in necrotrophs. The secretion and presence of these enzymes in the $W$. carpophilus showed its stronger resemblance to the necrotrophic plant pathogens. Unlike biotrophs, the necrotrophs have significantly expanded set of cell wall degrading enzymes, thus secretome of the $W$. carpophilus suggests necrotrophic behavior of the pathogen. The secretome of the fungus revealed some other proteins that also suggests its necrotrophic behavior such as FAD binding domains that have ability to catalyse various biochemical reactions and are mainly involved in electron transport chain ${ }^{26}$. We also found some other secretory proteins such as chaperone proteins also known as heat shock proteins that play an important role in the pathogenesis. They maintain the integrity of the pathogen in the adverse conditions, thus making it more viable for infection ${ }^{27}$. Laccasse precursor that plays an important role in lignin depolymerization of infected host ${ }^{28}$ and number of other enzymes such as endo-1, 4-beta-galactosidase, cutinase, rhamnogalacturonan lyase, pectin-esterase, pectate lyase, lipolytic protein etc. that play a crucial role in the pathogenicity. Surprisingly, some pathogenicity determinants that plays a role in disarming the host defense such as mycelial catalases that are known to degrade the hydrogen peroxide produced by the host as a result of oxidative burst to kill the pathogen 
29 . The presence of these enzymes suggests that the pathogen secrete diverse proteins that co-ordinate in an organized manner to cause disease and evade the host defense. However, these pathogenicity determinants need further characterization and validation to get in depth insight of pathogenicity mechanism of the fungus. In our previous study, we were successful in transforming the fungus by using random ATMT method and the transformants were unable to cause the disease ${ }^{10}$. However, the present study has revealed the number of pathogenicity genes that can be easily targeted to render pathogen ineffective. The present study has opened new opportunities for the comprehensive genomic study of a variety of biological, metabolic and pathological aspects that make the $W$. carpophilus a successful necrotrophic pathogen. Therefore, it is an opportune time to go beyond the conventional neutral genetics by identifying, analyzing, site specific targeting of pathogenicity determinants and re-modelling the core effector repositories.

\section{Declarations}

\section{Acknowledgment}

The authors are highly thankful to M/S Xcelris Labs Limited, Ahmedabad-380015, India, for their service and help provided during the present study.

\section{Conflict of interest}

The authors declare no conflict of interest during the present study

\section{References}

1. Nabi, A., Padder, B., Dar, M. \& Ahmad, M. Morpho-cultural, pathological and molecular variability in Thyrostroma carpophilum causing shot hole of stone fruits in India. European Journal of Plant Pathology. 151, 613-627 (2018).

2. Bird, G. W. et al. Compendium of stone fruit diseases (The American Phytopathological Society, 1995).

3. Youssefi, A. \& Hajian Shahri, M. Shot hole disease, survival and pathogenicity of the causal agent on stone fruit trees in Northeast Iran. Journal of Crop Protection. 3, 563-572 (2014).

4. Väcäroju, C., Zalä, C. \& Cristea, S. in scientific conferences with international participation durable agriculture-Agriculture of future, 4th edition. Craiova (Romania): Faculty of Agriculture, University of Craiova.

5. Ye, S. et al. DNA Phylogeny, and Pathogenicity of Wilsonomyces carpophilus Isolate Causing ShotHole Disease of Prunus divaricata and Prunus armeniaca in Wild-Fruit Forest of Western Tianshan Mountains, China. Forests. 11, 319 (2020).

6. Marin-Felix, Y. et al. Genera of phytopathogenic fungi: GOPHY 1. Studies in mycology. 86, 99-216 https://doi.org/10.1016/j.simyco.2017.04.002 (2017). 
7. Ivanová, H., Kalocaiová, M. \& Bolvansky, M. Shot-hole disease on Prunus persica-the morphology and biology of Stigmina carpophila. Folia Oecologica. 39, 21 (2012).

8. Raabe, R. Shot hole of Catalina Cherry.Phytopathology47 (1957).

9. Ellis, M. B. Clasterosporium and some allied Dematiaceae-Phragmosporae, I, II. Mycological Papers(1959).

10. Rasool, R. S. et al. Thyrostroma carpophilum insertional mutagenesis: A step towards understanding its pathogenicity mechanism. J Microbiol Methods. 171, 105885 https://doi.org/10.1016/j.mimet.2020.105885 (2020).

11. Mahmoud, M., Zywicki, M., Twardowski, T. \& Karlowski, W. M. Efficiency of PacBio long read correction by 2nd generation Illumina sequencing. Genomics. 111, 43-49 (2019).

12. Steiner, C. C., Putnam, A. S. \& Hoeck, P. E. \& Ryder, O. A. Conservation genomics of threatened animal species. Annu. Rev. Anim. Biosci. 1, 261-281 (2013).

13. Liu, Z. et al. SnTox3 acts in effector triggered susceptibility to induce disease on wheat carrying the Snn3 gene. PLoS Pathog. 5, e1000581 https://doi.org/10.1371/journal.ppat.1000581 (2009).

14. Eddleman, H. Making bacteria media from potato.Indiana Biolab(1998).

15. Nabi, A. et al. Morphological characterisation and media preferences in Wilsonomyces carpophilus, the causal agent of shot hole disease of stone fruits in Kashmir. Journal of Pharmacognosy and Phytochemistry. 7, 1326-1331 (2018).

16. Aragona, M. et al. De novo genome assembly of the soil-borne fungus and tomato pathogen Pyrenochaeta lycopersici. BMC genomics. 15, 313 (2014).

17. Samuel, G. On the shot-hole disease caused by Clasterosporium carpophilum and on the'shothole'effect. Annals of Botany. 41, 375-404 (1927).

18. Adaskaveg, J., Shaw, D. \& Ogawa, J. A mist generator and environmental monitoring system for field studies on shothole disease of almond. Plant disease. 74, 558-562 (1990).

19. Wilson, E. E. The shot-hole disease of stone-fruit trees (No. Folleto1106). (1937).

20. Hall, C., Welch, J., Kowbel, D. J. \& Glass, N. L. Evolution and diversity of a fungal self/nonself recognition locus. PloS one. 5, e14055 (2010).

21. Tuite, M. F. \& Serio, T. R. The prion hypothesis: from biological anomaly to basic regulatory mechanism. Nature reviews Molecular cell biology. 11, 823-833 (2010).

22. Breen, S., Solomon, P. S., Bedon, F. \& Vincent, D. Surveying the potential of secreted antimicrobial peptides to enhance plant disease resistance. Frontiers in plant science. 6, 900 (2015).

23. Shin, J., Kim, J. E., Lee, Y. W. \& Son, H. Fungal cytochrome P450s and the P450 complement (CYPome) of Fusarium graminearum. Toxins. 10, 112 (2018).

24. Turrà, D., Segorbe, D. \& Di Pietro, A. Protein kinases in plant-pathogenic fungi: conserved regulators of infection. Annual Review of Phytopathology. 52, 267-288 (2014).

25. Condon, B. J. et al. Comparative genome structure, secondary metabolite, and effector coding capacity across Cochliobolus pathogens. PLoS Genet. 9, e1003233 (2013). 
26. Pigné, S. et al. A flavoprotein supports cell wall properties in the necrotrophic fungus Alternaria brassicicola. Fungal biology and biotechnology. 4, 1-13 (2017).

27. Neckers, L. \& Tatu, U. Molecular chaperones in pathogen virulence: emerging new targets for therapy. Cell host \& microbe. 4, 519-527 (2008).

28. Edens, W. A., Goins, T. Q., Dooley, D. \& Henson, J. M. Purification and characterization of a secreted laccase of Gaeumannomyces graminis var. tritici. Applied and Environmental Microbiology. 65, 3071-3074 (1999).

29. Garre, V., Tenberge, K. B. \& Eising, R. Secretion of a fungal extracellular catalase by Claviceps purpurea during infection of rye: putative role in pathogenicity and suppression of host defense. Phytopathology. 88, 744-753 (1998).

\section{Tables}

Table 1: Genomic characteristics of Wilsonomyces carpophilus

\begin{tabular}{|ll|}
\hline Characteristics & Value \\
\hline Total no of scaffolds & 130 \\
\hline Total genome size including gaps ('Ns') & 29992279 \\
\hline Total genome size without gaps ('Ns') & 29984629 \\
\hline Scaffolds N50 & 662300 \\
\hline Average scaffold length & 117586 \\
\hline Maximum scaffold length & 2185089 \\
\hline GC content & $49.77 \%$ \\
\hline
\end{tabular}

Table 2: Distribution of secreted proteins throughout the Wilsonomyces carpophilus genome 


\begin{tabular}{|c|c|c|c|c|}
\hline Secreted protein & $\begin{array}{l}\text { Scaffold } \\
\text { no. }\end{array}$ & $\begin{array}{l}\text { Gene } \\
\text { no. }\end{array}$ & $\begin{array}{l}\text { e- } \\
\text { value }\end{array}$ & Species \\
\hline FAD binding domain-containing protein & $\begin{array}{l}\text { Scaffold } \\
43\end{array}$ & $\begin{array}{l}\text { gene } \\
9152\end{array}$ & $\begin{array}{l}1.00 \mathrm{E}- \\
83\end{array}$ & Magnaporthe oryzae \\
\hline Ricin B lectin & $\begin{array}{l}\text { Scaffold } \\
46\end{array}$ & $\begin{array}{l}\text { gene } \\
9390\end{array}$ & $\begin{array}{l}9.00 \mathrm{E}- \\
13\end{array}$ & $\begin{array}{l}\text { Clostridium } \\
\text { thermocellum }\end{array}$ \\
\hline Protein disulfide-isomerase tigA precursor & $\begin{array}{l}\text { Scaffold } \\
47\end{array}$ & $\begin{array}{l}\text { gene } \\
9460\end{array}$ & $\begin{array}{l}2.00 \mathrm{E}- \\
110\end{array}$ & Neurospora crassa \\
\hline Protein disulfide isomerase & $\begin{array}{l}\text { Scaffold } \\
47\end{array}$ & $\begin{array}{l}\text { gene } \\
9460\end{array}$ & $\begin{array}{l}1.00 \mathrm{E}- \\
52\end{array}$ & $\begin{array}{l}\text { Dictyostelium } \\
\text { discoideum }\end{array}$ \\
\hline Para-nitrobenzyl esterase & $\begin{array}{l}\text { Scaffold } \\
48\end{array}$ & $\begin{array}{l}\text { gene } \\
9543\end{array}$ & $\begin{array}{l}2.00 \mathrm{E}- \\
138\end{array}$ & Magnaporthe oryzae \\
\hline Probable galactose oxidase precursor & $\begin{array}{l}\text { Scaffold } \\
50\end{array}$ & $\begin{array}{l}\text { gene } \\
9571\end{array}$ & $\begin{array}{l}4.00 \mathrm{E}- \\
125\end{array}$ & Neurospora crassa \\
\hline Kelch repeat-containing protein & $\begin{array}{l}\text { Scaffold } \\
50\end{array}$ & $\begin{array}{l}\text { gene } \\
9571\end{array}$ & $\begin{array}{l}2.00 \mathrm{E}- \\
29\end{array}$ & Nostoc punctiforme \\
\hline Probable exported protease & $\begin{array}{l}\text { Scaffold } \\
55\end{array}$ & $\begin{array}{l}\text { gene } \\
9807\end{array}$ & $\begin{array}{l}4.00 \mathrm{E}- \\
15\end{array}$ & $\begin{array}{l}\text { Mycobacterium } \\
\text { tuberculosis }\end{array}$ \\
\hline Laccase precursor & $\begin{array}{l}\text { Scaffold } \\
65\end{array}$ & $\begin{array}{l}\text { gene } \\
10095\end{array}$ & $\begin{array}{l}4.00 \mathrm{E}- \\
127\end{array}$ & Neurospora crassa \\
\hline Laccase precursor & $\begin{array}{l}\text { Scaffold } \\
89\end{array}$ & $\begin{array}{l}\text { gene } \\
10486\end{array}$ & $\begin{array}{l}9.00 \mathrm{E}- \\
132\end{array}$ & Neurospora crassa \\
\hline Endoglucanase IV precursor & $\begin{array}{l}\text { Scaffold } \\
98\end{array}$ & $\begin{array}{l}\text { gene } \\
10521\end{array}$ & $\begin{array}{l}2.00 \mathrm{E}- \\
22\end{array}$ & Neurospora crassa \\
\hline Alpha-Glucosidase precursor & $\begin{array}{l}\text { Scaffold } \\
112\end{array}$ & $\begin{array}{l}\text { gene } \\
10729\end{array}$ & $\begin{array}{l}2.00 \mathrm{E}- \\
168\end{array}$ & Neurospora crassa \\
\hline G-D-S-L lipolytic protein & $\begin{array}{l}\text { Scaffold } \\
1\end{array}$ & $\begin{array}{l}\text { gene } \\
106\end{array}$ & $\begin{array}{l}4.00 \mathrm{E}- \\
13\end{array}$ & $\begin{array}{l}\text { Clostridium } \\
\text { thermocellum }\end{array}$ \\
\hline G-D-S-L lipolytic protein & $\begin{array}{l}\text { Scaffold } \\
1\end{array}$ & $\begin{array}{l}\text { gene } \\
106\end{array}$ & $\begin{array}{l}6.00 \mathrm{E}- \\
06\end{array}$ & $\begin{array}{l}\text { Clostridium } \\
\text { thermocellum }\end{array}$ \\
\hline Probable DFG5 protein & $\begin{array}{l}\text { Scaffold } \\
1\end{array}$ & $\begin{array}{l}\text { gene } \\
360\end{array}$ & $\begin{array}{l}2.00 \mathrm{E}- \\
92\end{array}$ & Neurospora crassa \\
\hline Phospholipase /carboxylesterase & $\begin{array}{l}\text { Scaffold } \\
2\end{array}$ & $\begin{array}{l}\text { gene } \\
657\end{array}$ & $\begin{array}{l}2.00 \mathrm{E}- \\
16\end{array}$ & $\begin{array}{l}\text { Trichodesmium } \\
\text { erythraeum }\end{array}$ \\
\hline Probable DFG5 protein & $2^{\text {Scaffold }}$ & $\begin{array}{l}\text { gene } \\
661\end{array}$ & $\begin{array}{l}4.00 \mathrm{E}- \\
102\end{array}$ & Neurospora crassa \\
\hline Beta-Hexosaminidase & $\begin{array}{l}\text { Scaffold } \\
2\end{array}$ & $\begin{array}{l}\text { gene } \\
715\end{array}$ & $\begin{array}{l}3.00 \mathrm{E}- \\
25\end{array}$ & Xylella fastidiosa \\
\hline CATB_EMENI Catalase B & $\begin{array}{l}\text { Scaffold } \\
\text { Page } 12 / 25\end{array}$ & gene & 0 & Aspergillus nidulans \\
\hline
\end{tabular}




\begin{tabular}{|c|c|c|c|c|}
\hline & 2 & 809 & & \\
\hline Mycelial catalase Cat1 & $\begin{array}{l}\text { Scaffold } \\
2\end{array}$ & $\begin{array}{l}\text { gene } \\
809\end{array}$ & 0 & Aspergillus fumigatus \\
\hline Catalase 3 precursor & $\begin{array}{l}\text { Scaffold } \\
2\end{array}$ & $\begin{array}{l}\text { gene } \\
809\end{array}$ & 0 & Neurospora crassa \\
\hline Chaperone protein DnaJ & $\begin{array}{l}\text { Scaffold } \\
2\end{array}$ & $\begin{array}{l}\text { gene } \\
963\end{array}$ & $\begin{array}{l}3.00 \mathrm{E}- \\
50\end{array}$ & Xylella fastidiosa \\
\hline Endo-1, 4-beta-galactosidase & $\begin{array}{l}\text { Scaffold } \\
4\end{array}$ & $\begin{array}{l}\text { gene } \\
1832\end{array}$ & $\begin{array}{l}6.00 \mathrm{E}- \\
127\end{array}$ & Neurospora crassa \\
\hline Glycosyl hydrolase family 53 & $\begin{array}{l}\text { Scaffold } \\
4\end{array}$ & $\begin{array}{l}\text { gene } \\
1832\end{array}$ & $\begin{array}{l}9.00 \mathrm{E}- \\
55\end{array}$ & Enterococcus faecium \\
\hline Protein ATG-5, isoform c & $\begin{array}{l}\text { Scaffold } \\
6\end{array}$ & $\begin{array}{l}\text { gene } \\
2389\end{array}$ & $\begin{array}{l}3.00 \mathrm{E}- \\
16\end{array}$ & $\begin{array}{l}\text { Caenorhabditis } \\
\text { elegans }\end{array}$ \\
\hline Cutinase & $\begin{array}{l}\text { Scaffold } \\
6\end{array}$ & $\begin{array}{l}\text { gene } \\
2543\end{array}$ & $\begin{array}{l}8.00 \mathrm{E}- \\
08\end{array}$ & Mycobacterium bovis \\
\hline Vacuolar protease A precursor & $\begin{array}{l}\text { Scaffold } \\
6\end{array}$ & $\begin{array}{l}\text { gene } \\
2597\end{array}$ & $\begin{array}{l}6.00 \mathrm{E}- \\
21\end{array}$ & Neurospora crassa \\
\hline AGAP003277-PA & $\begin{array}{l}\text { Scaffold } \\
6\end{array}$ & $\begin{array}{l}\text { gene } \\
2597\end{array}$ & $\begin{array}{l}2.00 \mathrm{E}- \\
18\end{array}$ & Anopheles gambiae \\
\hline Acetylornithine deacetylase & $\begin{array}{l}\text { Scaffold } \\
6\end{array}$ & $\begin{array}{l}\text { gene } \\
2686\end{array}$ & $\begin{array}{l}2.00 \mathrm{E}- \\
29\end{array}$ & $\begin{array}{l}\text { Actinobacillus } \\
\text { pleuropneumoniae }\end{array}$ \\
\hline Phytase & $\begin{array}{l}\text { Scaffold } \\
8\end{array}$ & $\begin{array}{l}\text { gene } \\
3185\end{array}$ & $\begin{array}{l}2.00 \mathrm{E}- \\
08\end{array}$ & Nostoc punctiforme \\
\hline $\begin{array}{l}\text { Rhamnogalacturonan acetylesterase } \\
\text { precursor }\end{array}$ & $\begin{array}{l}\text { Scaffold } \\
8\end{array}$ & $\begin{array}{l}\text { gene } \\
3288\end{array}$ & $\begin{array}{l}2.00 \mathrm{E}- \\
72\end{array}$ & Neurospora crassa \\
\hline G-D-S-L lipolytic protein & $\begin{array}{l}\text { Scaffold } \\
8\end{array}$ & $\begin{array}{l}\text { gene } \\
3288\end{array}$ & $\begin{array}{l}4.00 \mathrm{E}- \\
19\end{array}$ & $\begin{array}{l}\text { Clostridium } \\
\text { thermocellum }\end{array}$ \\
\hline G-D-S-L lipolytic protein & $\begin{array}{l}\text { Scaffold } \\
8\end{array}$ & $\begin{array}{l}\text { gene } \\
3288\end{array}$ & $\begin{array}{l}8.00 \mathrm{E}- \\
08\end{array}$ & $\begin{array}{l}\text { Clostridium } \\
\text { thermocellum }\end{array}$ \\
\hline $\begin{array}{l}\text { Glycerophosphoryl diester } \\
\text { phosphodiesterase }\end{array}$ & $\begin{array}{l}\text { Scaffold } \\
9\end{array}$ & $\begin{array}{l}\text { gene } \\
3772\end{array}$ & $\begin{array}{l}6.00 \mathrm{E}- \\
12\end{array}$ & Nostoc punctiforme \\
\hline $\begin{array}{l}\text { Glycerophosphoryl diester } \\
\text { phosphodiesterase }\end{array}$ & $\begin{array}{l}\text { Scaffold } \\
9\end{array}$ & $\begin{array}{l}\text { gene } \\
3772\end{array}$ & $\begin{array}{l}1.00 \mathrm{E}- \\
10\end{array}$ & Nostoc punctiforme \\
\hline L-asparaginase II & $\begin{array}{l}\text { Scaffold } \\
10\end{array}$ & $\begin{array}{l}\text { gene } \\
4114\end{array}$ & $\begin{array}{l}2.00 \mathrm{E}- \\
65\end{array}$ & Yersinia pestis \\
\hline Type II L-Asparaginase & $\begin{array}{l}\text { Scaffold } \\
10\end{array}$ & $\begin{array}{l}\text { gene } \\
4114\end{array}$ & $\begin{array}{l}1.00 \mathrm{E}- \\
49\end{array}$ & Azotobacter vinelandii \\
\hline Rhamnogalacturonan lyase & $\begin{array}{l}\text { Scaffold } \\
12\end{array}$ & $\begin{array}{l}\text { gene } \\
4368\end{array}$ & $\begin{array}{l}7.00 \mathrm{E}- \\
21\end{array}$ & Aspergillus nidulans \\
\hline
\end{tabular}




\begin{tabular}{|c|c|c|c|c|}
\hline Rhamnogalacturonase & $\begin{array}{l}\text { Scaffold } \\
12\end{array}$ & $\begin{array}{l}\text { gene } \\
4368\end{array}$ & $\begin{array}{l}3.00 \mathrm{E}- \\
19\end{array}$ & \\
\hline Alpha-1,6-mannosyltransferase & $\begin{array}{l}\text { Scaffold } \\
12\end{array}$ & $\begin{array}{l}\text { gene } \\
4398\end{array}$ & $\begin{array}{l}2.00 \mathrm{E}- \\
91\end{array}$ & Magnaporthe oryzae \\
\hline Histidine kinase & $\begin{array}{l}\text { Scaffold } \\
12\end{array}$ & $\begin{array}{l}\text { gene } \\
4401\end{array}$ & $\begin{array}{l}2.00 \mathrm{E}- \\
15\end{array}$ & $\begin{array}{l}\text { Cytophaga } \\
\text { hutchinsonii }\end{array}$ \\
\hline Calcium-related spray protein & $\begin{array}{l}\text { Scaffold } \\
12\end{array}$ & $\begin{array}{l}\text { gene } \\
4405\end{array}$ & $\begin{array}{l}3.00 \mathrm{E}- \\
29\end{array}$ & Neurospora crassa \\
\hline Carboxypeptidase A4 preproprotein & $\begin{array}{l}\text { Scaffold } \\
12\end{array}$ & $\begin{array}{l}\text { gene } \\
4449\end{array}$ & $\begin{array}{l}7.00 \mathrm{E}- \\
06\end{array}$ & Homo sapiens \\
\hline Beta (1-3) glucanosyltransferase & $\begin{array}{l}\text { Scaffold } \\
12\end{array}$ & $\begin{array}{l}\text { gene } \\
4500\end{array}$ & $\begin{array}{l}5.00 \mathrm{E}- \\
148\end{array}$ & Neurospora crassa \\
\hline $\begin{array}{l}\text { Dolichyl-phosphate-mannose-protein } \\
\text { mannosyltransferase } 1\end{array}$ & $\begin{array}{l}\text { Scaffold } \\
16\end{array}$ & $\begin{array}{l}\text { gene } \\
4860\end{array}$ & $\begin{array}{l}1.00 \mathrm{E}- \\
31\end{array}$ & Magnaporthe oryzae \\
\hline Phospholipase/carboxylesterase & $\begin{array}{l}\text { Scaffold } \\
17\end{array}$ & $\begin{array}{l}\text { gene } \\
5083\end{array}$ & $\begin{array}{l}1.00 \mathrm{E}- \\
12\end{array}$ & Nostoc punctiforme \\
\hline Possible conserved lipoprotein LpqP & $\begin{array}{l}\text { Scaffold } \\
17\end{array}$ & $\begin{array}{l}\text { gene } \\
5083\end{array}$ & $\begin{array}{l}2.00 \mathrm{E}- \\
08\end{array}$ & $\begin{array}{l}\text { Mycobacterium } \\
\text { tuberculosis }\end{array}$ \\
\hline Pectin-esterase & $\begin{array}{l}\text { Scaffold } \\
18\end{array}$ & $\begin{array}{l}\text { gene } \\
5419\end{array}$ & $\begin{array}{l}1.00 \mathrm{E}- \\
29\end{array}$ & $\begin{array}{l}\text { Clostridium } \\
\text { thermocellum }\end{array}$ \\
\hline Cathepsin D & $\begin{array}{l}\text { Scaffold } \\
18\end{array}$ & $\begin{array}{l}\text { gene } \\
5432\end{array}$ & $\begin{array}{l}2.00 \mathrm{E}- \\
30\end{array}$ & $\begin{array}{l}\text { Dictyostelium } \\
\text { discoideum }\end{array}$ \\
\hline Aspartic endopeptidase Pep2 & $\begin{array}{l}\text { Scaffold } \\
18\end{array}$ & $\begin{array}{l}\text { gene } \\
5432\end{array}$ & $\begin{array}{l}9.00 \mathrm{E}- \\
28\end{array}$ & Aspergillus fumigatus \\
\hline Beta-glucosidase & $\begin{array}{l}\text { Scaffold } \\
19\end{array}$ & $\begin{array}{l}\text { gene } \\
5495\end{array}$ & $\begin{array}{l}6.00 \mathrm{E}- \\
46\end{array}$ & Neurospora crassa \\
\hline Glycosyl Hydrolase Family 88 & $\begin{array}{l}\text { Scaffold } \\
20\end{array}$ & $\begin{array}{l}\text { gene } \\
5660\end{array}$ & $\begin{array}{l}2.00 \mathrm{E}- \\
49\end{array}$ & Enterococcus faecium \\
\hline Crystal protein & $\begin{array}{l}\text { Scaffold } \\
21\end{array}$ & $\begin{array}{l}\text { gene } \\
5861\end{array}$ & $\begin{array}{l}1.00 \mathrm{E}- \\
23\end{array}$ & $\begin{array}{l}\text { Dictyostelium } \\
\text { discoideum }\end{array}$ \\
\hline Carboxypeptidase A2 (pancreatic) & $\begin{array}{l}\text { Scaffold } \\
22\end{array}$ & $\begin{array}{l}\text { gene } \\
6186\end{array}$ & $\begin{array}{l}1.00 \mathrm{E}- \\
18\end{array}$ & Homo sapiens \\
\hline Carboxypeptidase A4 preproprotein & $\begin{array}{l}\text { Scaffold } \\
22\end{array}$ & $\begin{array}{l}\text { gene } \\
6186\end{array}$ & $\begin{array}{l}3.00 \mathrm{E}- \\
18\end{array}$ & Homo sapiens \\
\hline Galactose oxidase precursor & $\begin{array}{l}\text { Scaffold } \\
22\end{array}$ & $\begin{array}{l}\text { gene } \\
6227\end{array}$ & $\begin{array}{l}4.00 \mathrm{E}- \\
47\end{array}$ & Neurospora crassa \\
\hline Pectate lyase precursor & $\begin{array}{l}\text { Scaffold } \\
27\end{array}$ & $\begin{array}{l}\text { gene } \\
7051\end{array}$ & $\begin{array}{l}3.00 \mathrm{E}- \\
48\end{array}$ & Aspergillus nidulans \\
\hline Pectate lyase & $\begin{array}{l}\text { Scaffold } \\
27\end{array}$ & $\begin{array}{l}\text { gene } \\
7051\end{array}$ & $\begin{array}{l}1.00 \mathrm{E}- \\
18\end{array}$ & $\begin{array}{l}\text { Cytophaga } \\
\text { hutchinsonii }\end{array}$ \\
\hline
\end{tabular}




\begin{tabular}{|c|c|c|c|c|}
\hline Oryzin & $\begin{array}{l}\text { Scaffold } \\
29\end{array}$ & $\begin{array}{l}\text { gene } \\
7186\end{array}$ & $\begin{array}{l}1.00 \mathrm{E}- \\
104\end{array}$ & Magnaporthe oryzae \\
\hline Acetylxylan esterase precursor & $\begin{array}{l}\text { Scaffold } \\
32\end{array}$ & $\begin{array}{l}\text { gene } \\
7974\end{array}$ & $\begin{array}{l}9.00 \mathrm{E}- \\
82\end{array}$ & Neurospora crassa \\
\hline Aliphatic nitrilase & $\begin{array}{l}\text { Scaffold } \\
32\end{array}$ & $\begin{array}{l}\text { gene } \\
8021\end{array}$ & $\begin{array}{l}2.00 \mathrm{E}- \\
07\end{array}$ & Neurospora crassa \\
\hline Proteinase T precursor & $\begin{array}{l}\text { Scaffold } \\
34\end{array}$ & $\begin{array}{l}\text { gene } \\
8276\end{array}$ & $\begin{array}{l}4.00 \mathrm{E}- \\
18\end{array}$ & Neurospora crassa \\
\hline Autophagic serine protease Alp2 & $\begin{array}{l}\text { Scaffold } \\
34\end{array}$ & $\begin{array}{l}\text { gene } \\
8276\end{array}$ & $\begin{array}{l}5.00 \mathrm{E}- \\
118\end{array}$ & Aspergillus fumigatus \\
\hline Proteinase T precursor & $\begin{array}{l}\text { Scaffold } \\
34\end{array}$ & $\begin{array}{l}\text { gene } \\
8277\end{array}$ & $\begin{array}{l}3.00 \mathrm{E}- \\
68\end{array}$ & Neurospora crassa \\
\hline Autophagic serine protease Alp2 & $\begin{array}{l}\text { Scaffold } \\
34\end{array}$ & $\begin{array}{l}\text { gene } \\
8277\end{array}$ & $\begin{array}{l}9.00 \mathrm{E}- \\
67\end{array}$ & Aspergillus fumigatus \\
\hline Endoglucanase (carboxymethyl cellulase) & $\begin{array}{l}\text { Scaffold } \\
35\end{array}$ & $\begin{array}{l}\text { gene } \\
8314\end{array}$ & $\begin{array}{l}7.00 \mathrm{E}- \\
40\end{array}$ & $\begin{array}{l}\text { Mycobacterium } \\
\text { tuberculosis }\end{array}$ \\
\hline Carbonic anhydrase & $\begin{array}{l}\text { Scaffold } \\
35\end{array}$ & $\begin{array}{l}\text { gene } \\
8495\end{array}$ & $\begin{array}{l}4.00 \mathrm{E}- \\
15\end{array}$ & Vibrio cholerae \\
\hline Carbonic anhydrase & $\begin{array}{l}\text { Scaffold } \\
35\end{array}$ & $\begin{array}{l}\text { gene } \\
8495\end{array}$ & $\begin{array}{l}1.00 \mathrm{E}- \\
17\end{array}$ & Oenococcus oeni \\
\hline Actin-like protein 3 & $\begin{array}{l}\text { Scaffold } \\
38\end{array}$ & $\begin{array}{l}\text { gene } \\
8752\end{array}$ & $\begin{array}{l}1.00 \mathrm{E}- \\
17\end{array}$ & Aspergillus nidulans \\
\hline Actin-like protein 3 & $\begin{array}{l}\text { Scaffold } \\
38\end{array}$ & $\begin{array}{l}\text { gene } \\
8752\end{array}$ & $\begin{array}{l}2.00 \mathrm{E}- \\
176\end{array}$ & $\begin{array}{l}\text { Fusarium } \\
\text { graminearum }\end{array}$ \\
\hline Actin-like protein & $\begin{array}{l}\text { Scaffold } \\
38\end{array}$ & $\begin{array}{l}\text { gene } \\
8752\end{array}$ & $\begin{array}{l}1.00 \mathrm{E}- \\
168\end{array}$ & $\begin{array}{l}\text { Dictyostelium } \\
\text { discoideum }\end{array}$ \\
\hline Beta-glucuronidase isoform 1 precursor & $\begin{array}{l}\text { Scaffold } \\
41\end{array}$ & $\begin{array}{l}\text { gene } \\
8920\end{array}$ & $\begin{array}{l}9.00 \mathrm{E}- \\
120\end{array}$ & Homo sapiens \\
\hline Beta-D-glucuronidase & $\begin{array}{l}\text { Scaffold } \\
41\end{array}$ & $\begin{array}{l}\text { gene } \\
8920\end{array}$ & $\begin{array}{l}1.00 \mathrm{E}- \\
24\end{array}$ & Haemophilus somnus \\
\hline FAD binding domain-containing protein & $\begin{array}{l}\text { Scaffold } \\
41\end{array}$ & $\begin{array}{l}\text { gene } \\
8926\end{array}$ & $\begin{array}{l}8.00 \mathrm{E}- \\
22\end{array}$ & Magnaporthe oryzae \\
\hline FAD binding domain-containing protein & $\begin{array}{l}\text { Scaffold } \\
41\end{array}$ & $\begin{array}{l}\text { gene } \\
8926\end{array}$ & $\begin{array}{l}9.00 \mathrm{E}- \\
93\end{array}$ & Magnaporthe oryzae \\
\hline
\end{tabular}

Table 3: SSR distribution across the Wilsonomyces carpophilus genome 


\begin{tabular}{|ll|}
\hline SSR distribution & Count \\
\hline Total number of sequences examined & 130 \\
\hline Total size of examined sequences (bp) & 29987235 \\
\hline Total number of identified SSRs & 2851 \\
\hline Number of SSR containing sequences & 91 \\
\hline Number of sequences containing more than 1 SSR & 77 \\
\hline Number of sequences with 150bp flanking region & 2592 \\
\hline Number of dinucleotide motifs & 937 \\
\hline Number of trinucleotide motifs & 1362 \\
\hline Number of tetranucleotide motifs & 265 \\
\hline Number of pentanucleotide motifs & 141 \\
\hline Number of hexanucleotide motifs & 146 \\
\hline
\end{tabular}

Table 4: Pfam gene annotation of Wilsonomyces carpophilus genome

\begin{tabular}{|ll|}
\hline Pfam domain & Total \\
\hline Pkinase & 86 \\
\hline p450 & 69 \\
adh_short & 61 \\
Sugar_tr & 52 \\
AMP-binding & 37 \\
HET & 27 \\
COesterase & 24 \\
\hline AAA & 23 \\
\hline Aldo_ket_red & 21 \\
\hline DEAD & 21 \\
\hline
\end{tabular}

Table 5: Diverse metabolic processes of the Wilsonomyces carpophilus predicted using KEGG pathway analysis 


\begin{tabular}{|c|c|}
\hline Metabolic pathway & count \\
\hline Carbohydrate metabolism & 328 \\
\hline Energy metabolism & 117 \\
\hline Lipid metabolism & 173 \\
\hline Nucleotide metabolism & 73 \\
\hline Amino acid metabolism & 287 \\
\hline Metabolism of other amino acids & 68 \\
\hline Glycan biosynthesis and metabolism & 81 \\
\hline Metabolism of cofactors and vitamins & 128 \\
\hline Metabolism of terpenoids and polyketides & 27 \\
\hline Biosynthesis of other secondary metabolites & 48 \\
\hline Xenobiotics biodegradation and metabolism & 72 \\
\hline Transcription & 97 \\
\hline Translation & 264 \\
\hline Folding, sorting and degradation & 215 \\
\hline Replication and repair & 135 \\
\hline Membrane transport & 11 \\
\hline Signal transduction & 377 \\
\hline Transport and catabolism & 300 \\
\hline Cell motility & 17 \\
\hline Cell growth and death & 296 \\
\hline Cellular community - eukaryotes & 39 \\
\hline Cellular community - prokaryotes & 15 \\
\hline Development and regeneration & 14 \\
\hline Environmental adaptation & 67 \\
\hline Protein families: metabolism & 364 \\
\hline Protein families: genetic information processing & 1930 \\
\hline Protein families: signaling and cellular processes & 436 \\
\hline Unclassified: metabolism & 83 \\
\hline
\end{tabular}

Page 17/25 


\begin{tabular}{|ll|}
\hline Unclassified: genetic information processing & 4 \\
\hline Unclassified: signaling and cellular processes & 13 \\
\hline Poorly characterized & 33 \\
\hline
\end{tabular}

\section{Figures}

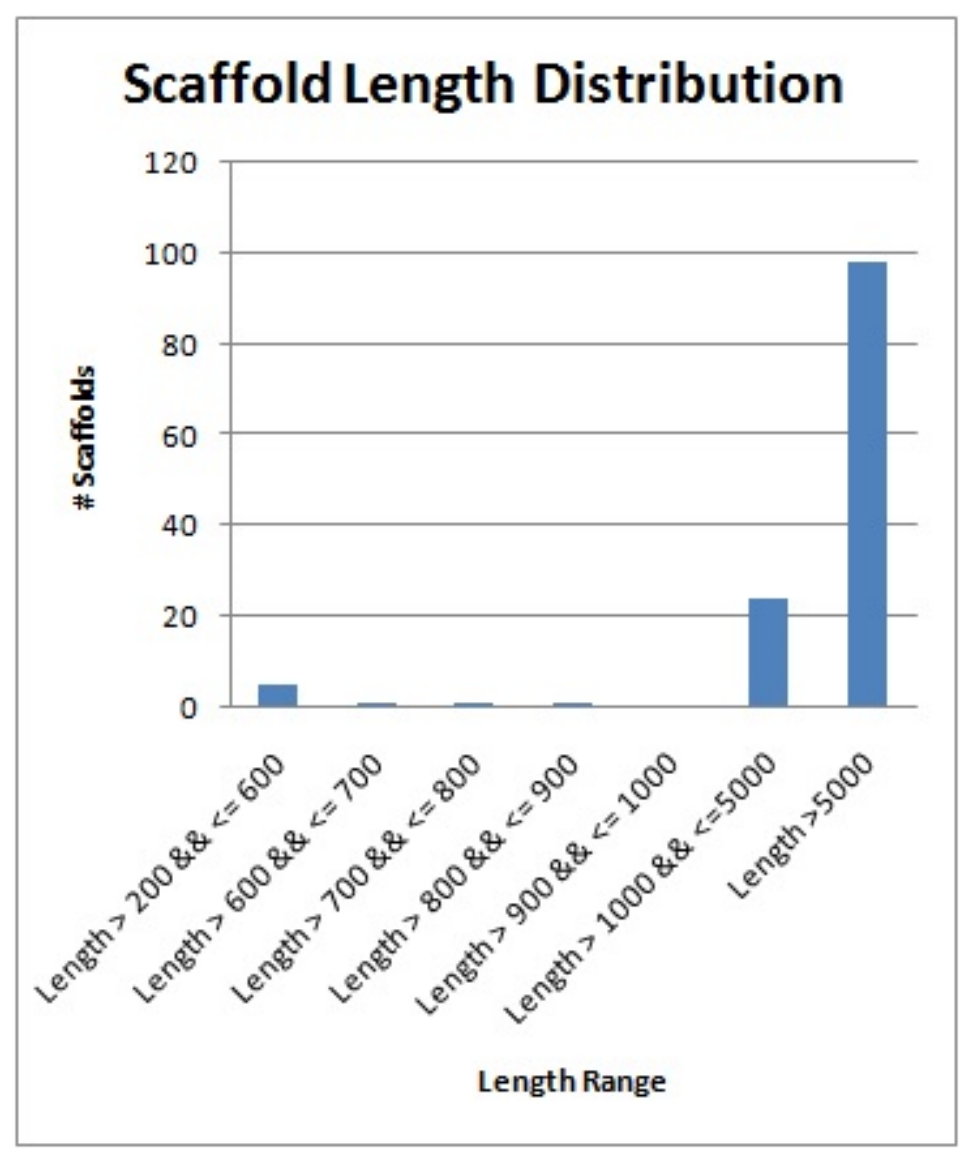

\section{Figure 1}

It represents scaffold length distribution across genome and maximum number of scaffolds has length above $5 \mathrm{~Kb}$. The least represented scaffold length is in between less than $1 \mathrm{~kb}$ to less than equal to $5 \mathrm{~kb}$. 




Figure 2

It signifies the correspondence of number of genes to the gene length and we found maximum number of genes have gene length in the range of $1 \mathrm{~Kb}$ to $5 \mathrm{~Kb}$ and very less number of genes have gene length above $5 \mathrm{~kb}$. 




Figure 3

Gene annotation for all the three GO domains i.e. Biological Processes (BP), Molecular Function (MF) and Cellular Components (CC). The bars represent the number of genes involved in the biological, cellular and molecular functions of the Wilsonomyces carpophilus genome. 


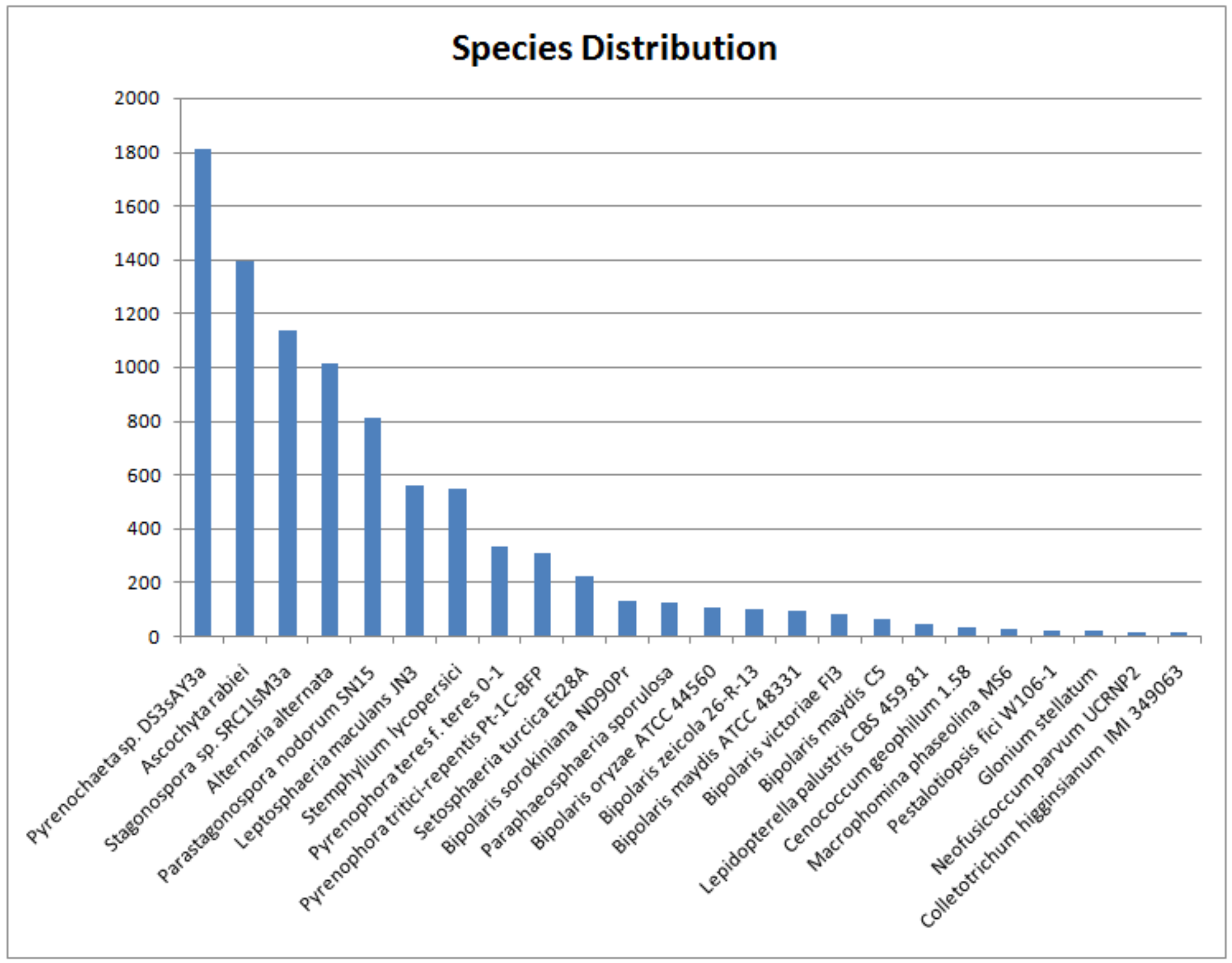

Figure 4

Relationship of other fungal species with Wilsonomyces carpophilus. The bars represent no. of hits attained in nrdata base against the Wilsonomyces carpophilus genome representing its similarity with other fungal plant pathogenic species with maximum similarity to Pyrenocheata species. 


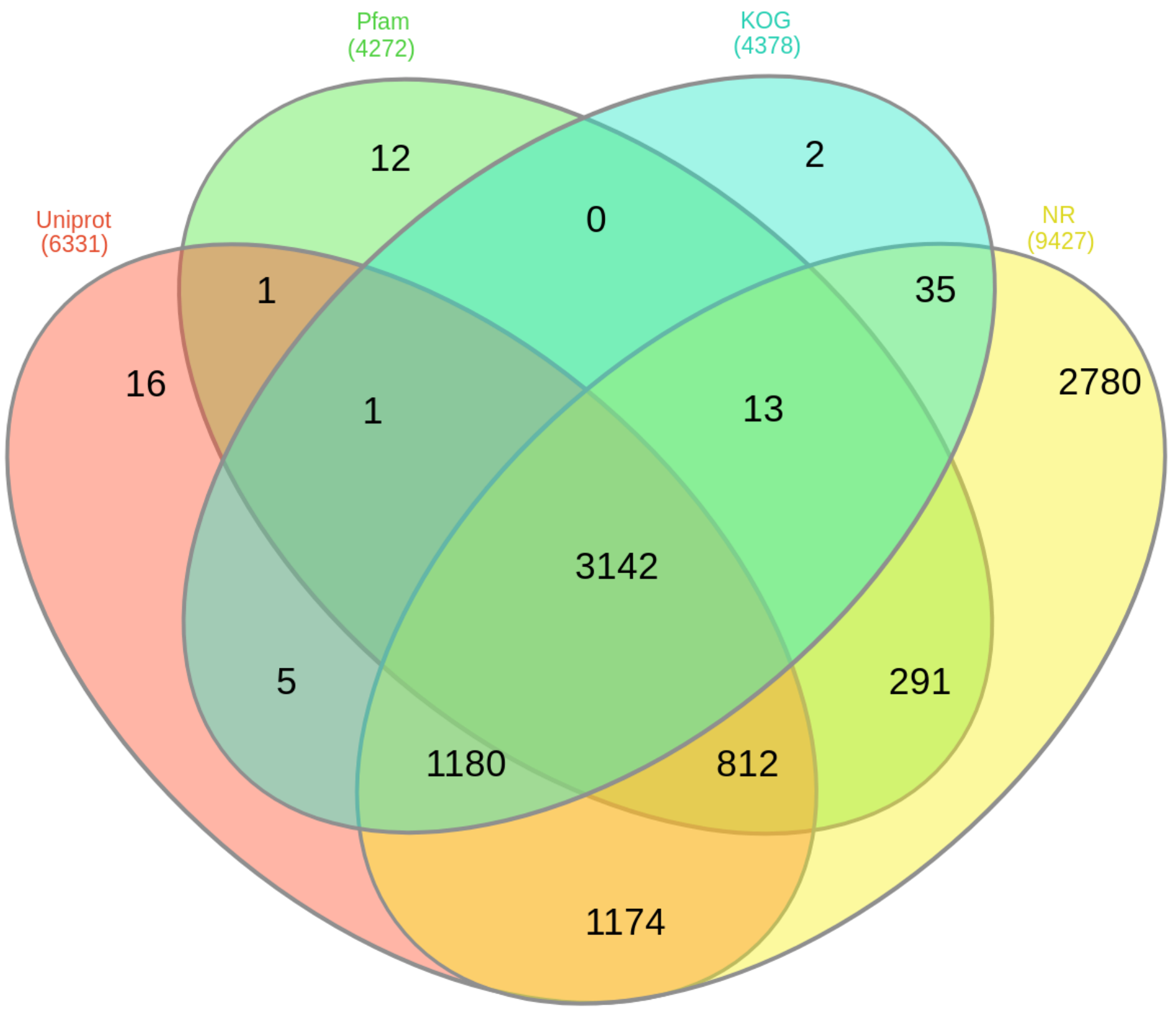

Figure 5

Venn diagram representing the number of genes that are common between and among the four data bases. The comparison between the data bases revealed that only 3142 genes are common to each data base out of 10901 genes. 


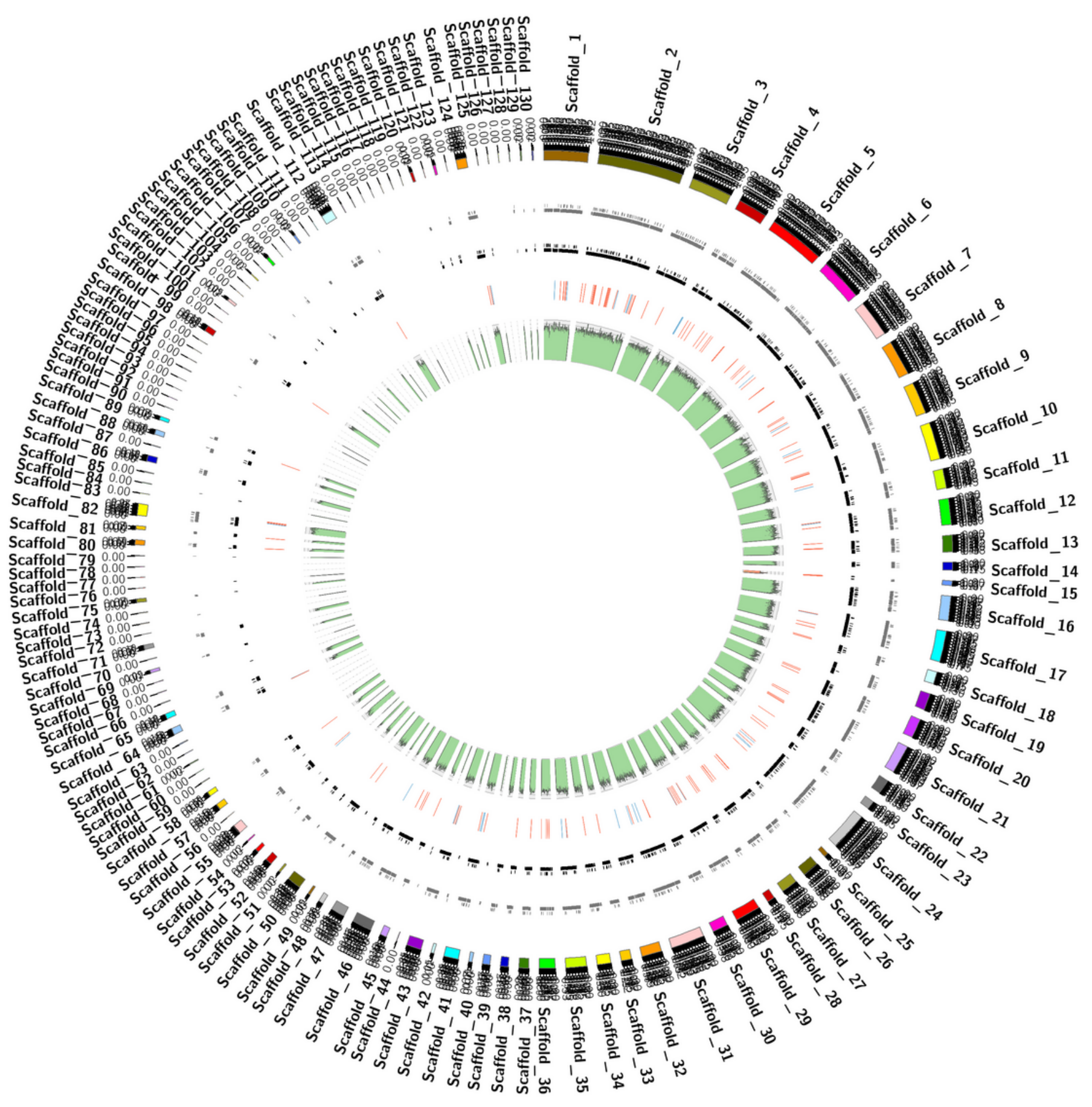

Figure 6

Schematic representation of genomic characteristics of Wilsonomyces carpophilus, Circle A and Circle B represents gene predicted in the positive frame. Circle $\mathrm{C}$ represents gene predicted in the negative frame, Circle D represents tRNA (red tiles) and rRNA (blue tiles). The inner E circle represents distribution of GC content . The red shade in the E circle represents regions of low GC contents (less than $35 \%$ ). 


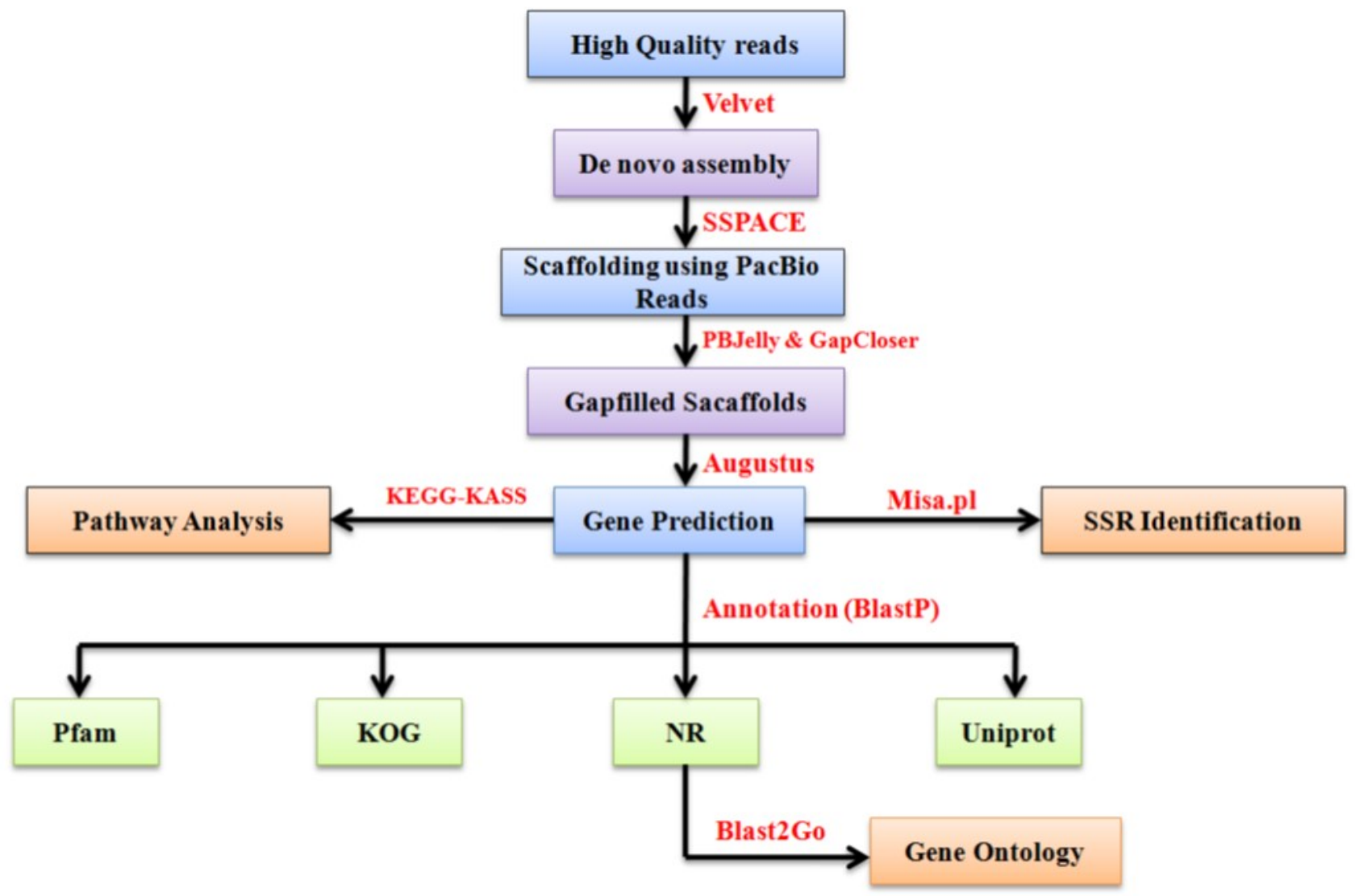

Figure 7

Schematic representation of steps employed in analyzing Wilsonomyces carpophilus genome using different software and databases. 




Figure 8

Bioinformatic pipeline used to find secreted proteins in the assembled genome of Wilsonomyces carpophilus

\section{Supplementary Files}

This is a list of supplementary files associated with this preprint. Click to download.

- SupplementaryTables12andfig1.pdf 